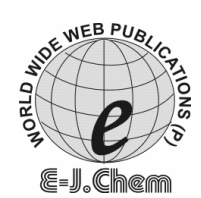

http://www.e-journals.net
ISSN: 0973-4945; CODEN ECJHAO

E-Journal of Chemistry 2008, 5(S1), 1008-1014

\title{
Synthesis and Study of Some Newer Analogues of Quinolin-8-ol as Potent Antimicrobial Agents
}

\author{
JYOTI SHARMA ${ }^{\S}$, SABIR HUSSAIN $^{\S *}$ and MOHAMMAD AMIR ${ }^{\#}$ \\ ${ }^{\S}$ Department of Chemistry, R. R. College, Alwar, Rajasthan \\ \#Department of Pharmaceutical Chemistry, \\ Jamia Hamdard, New Delhi. India. \\ 03shussain@gmail.com
}

Received 22 May 2008; Revised 19 June 2008; Accepted 23 June 2008

\begin{abstract}
New series of 4-(substituted phenyl)-5-[(quinolin-8-yloxy) methyl]4H-1,2,4-triazole-3-thiol (4a-c), $\mathrm{N}^{3}$-(4-substituted phenyl)-5-[(quinolin-8-yloxy) methyl]-4H-1,2,4-triazole-3,4-diamine (5a-c) and N-(4-substituted phenyl)-5[(quinolin-8-yloxy) methyl]-1,3,4-thiadiazol-2-amine (6a-g) have been synthesized and the structures of the new compounds were established on the basis of IR, ${ }^{1} \mathrm{H}$ NMR spectral data. In vitro antimicrobial activity (MIC activity) was evaluated and compared with standard drugs of loxacin and ketoconazole. Compounds $5 \mathbf{a}$ and $\mathbf{6 e}$ in the series have shown interesting antibacterial activity against both $S$. aureus (gram-positive) and E. coli (gram-negative) organisms. In this paper, we also describe studies leading to identification of antifungal agents. In the gratifying result, most of the compounds were found to have moderate antimicrobial activity.
\end{abstract}

Keywords: 1,2,4-Triazole, 1,3,4-Thiadiazole, Antibacterial, Antifungal.

\section{Introduction}

Heterocycles bearing a symmetrical triazole or 1,3,4-thiadiazole moieties represent an interesting class of compounds possessing a wide spectrum of biological activities such as anti-inflammatory ${ }^{1-3}$, antiviral ${ }^{4}$ and antimicrobial ${ }^{5,6}$ properties. It has also been reported in literature that derivative of 1,2,4-triazole and 1,3,4-thiadiazole condensed nucleus systems found that have diverse pharmacological activities such as antiinflammatory $^{7}$ antitumor $^{8}$, antifungal and antibacterial ${ }^{9}$. Furthermore, literature survey revealed that modification of the carboxyl function of representative non-steroidal anti-inflammatory drugs (NSAIDs) resulted in an increased anti-inflammatory activity with reduced ulcerogenic effect ${ }^{10-12}$. Our former studies ${ }^{13,14}$ have shown that certain compounds bearing 1,2,4-triazole and 1,3,4-thiadiazole nuclei possess significant 
anti-inflammatory activity with reduced gastrointestinal (GI) toxicity. we describe herein the synthesis of some triazole, thiadiazole derivatives and evaluation of their antimicrobial activities. The reaction sequence leading to the formation of desired heterocyclic compounds are outlined in Scheme 1. The structures of the compounds were assigned on the basis of IR, ${ }^{1} \mathrm{H}$ NMR spectral data.

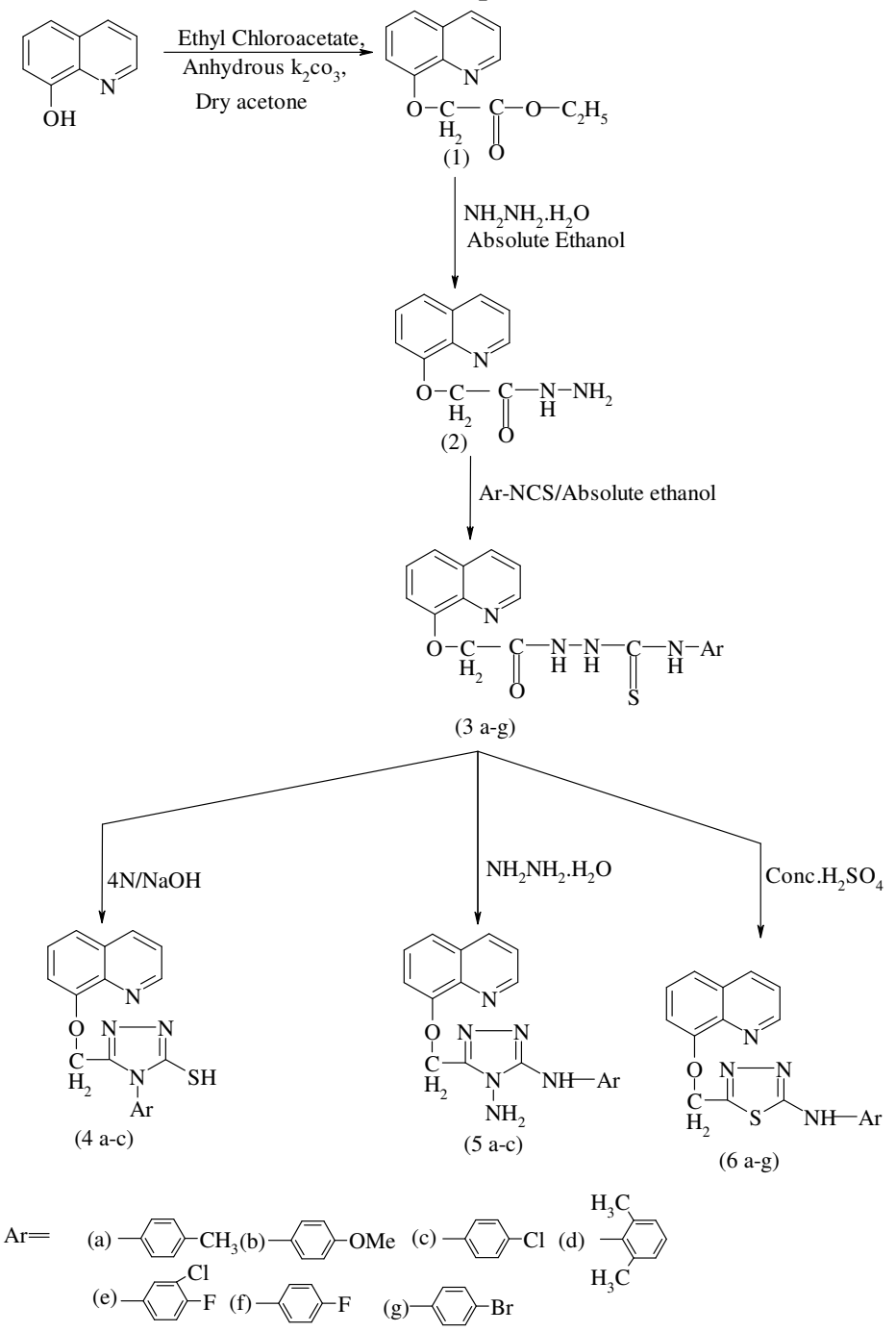

\section{Experimental}

Scheme 1

Melting points were determined in open capillary tubes. IR spectra were recorded on a perkin-Elmer 157 spectrometer and ${ }^{1}$ HNMR spectra on a Bucker WM-400 (400 MHZ FT NMR) spectrophotometer using TMS (Tetramethyl Silane) as internal reference (chemical shift in $\delta$ ppm). Purity of the compounds was checked by TLC (Thin Layer Chromatography) on silica gel plates and spot were visualized by exposure to iodine vapours. The physical data of the compounds prepared are presented in Table 1. 
Table 1. Characterization data of the compounds.

\begin{tabular}{|c|c|c|c|c|c|c|}
\hline Compounds & $\mathrm{Ar}$ & $\begin{array}{l}\text { M.P.P } \\
{ }^{\circ} \mathrm{C}\end{array}$ & $\begin{array}{c}\text { Yield, } \\
\%\end{array}$ & Mol. formula & $\begin{array}{l}\mathrm{N} \% \text {, } \\
\text { found }\end{array}$ & Calcd \\
\hline $4 \mathbf{a}$ & & 278 & 65 & $\mathrm{C}_{19} \mathrm{H}_{16} \mathrm{~N}_{4} \mathrm{OS}$ & 16.50 & 16.08 \\
\hline $4 b$ & & 281 & 57 & $\mathrm{C}_{19} \mathrm{H}_{16} \mathrm{~N}_{4} \mathrm{O}_{2} \mathrm{~S}$ & 15.84 & 15.37 \\
\hline $4 c$ & & 285 & 61 & $\mathrm{C}_{18} \mathrm{H}_{13} \mathrm{ClN}_{4} \mathrm{OS}$ & 15.40 & 15.19 \\
\hline $5 a$ & & 267 & 59 & $\mathrm{C}_{19} \mathrm{H}_{18} \mathrm{~N}_{6} \mathrm{O}$ & 24.40 & 24.26 \\
\hline $5 b$ & & 257 & 51 & $\mathrm{C}_{19} \mathrm{H}_{18} \mathrm{~N}_{6} \mathrm{O}_{2}$ & 23.25 & 23.19 \\
\hline $5 c$ & & 269 & 56 & $\mathrm{C}_{18} \mathrm{H}_{15} \mathrm{ClN}_{6} \mathrm{O}$ & 22.97 & 22.91 \\
\hline $6 \mathbf{a}$ & & 278 & 59 & $\mathrm{C}_{19} \mathrm{H}_{16} \mathrm{~N}_{4} \mathrm{OS}$ & 16.15 & 16.08 \\
\hline $6 b$ & & 265 & 57 & $\mathrm{C}_{19} \mathrm{H}_{16} \mathrm{~N}_{4} \mathrm{O}_{2} \mathrm{~S}$ & 15.45 & 15.37 \\
\hline $6 c$ & & 261 & 62 & $\mathrm{C}_{18} \mathrm{H}_{13} \mathrm{ClN}_{4} \mathrm{OS}$ & 15.35 & 15.19 \\
\hline 6d & & 272 & 64 & $\mathrm{C}_{20} \mathrm{H}_{18} \mathrm{~N}_{4} \mathrm{OS}$ & 15.66 & 15.46 \\
\hline $6 e$ & & 271 & 67 & $\mathrm{C}_{18} \mathrm{H}_{12} \mathrm{ClFN}_{4} \mathrm{OS}$ & 14.53 & 14.48 \\
\hline $6 f$ & & 275 & 58 & $\mathrm{C}_{18} \mathrm{H}_{13} \mathrm{FN}_{4} \mathrm{OS}$ & 16.10 & 15.90 \\
\hline $6 \mathrm{~g}$ & & 268 & 63 & $\mathrm{C}_{18} \mathrm{H}_{13} \mathrm{BrN}_{4} \mathrm{OS}$ & 13.71 & 13.56 \\
\hline
\end{tabular}

Ethyl (quinolin-8-yloxy) acetate (1)

To a solution of 8-hydroxy quinoline $(0.5$ mole $)$ in dry acetone $(150 \mathrm{~mL})$, ethyl chloroacetate $\left(0.60\right.$ mole) were added followed by anhydrous $\mathrm{K}_{2} \mathrm{CO}_{3}(1.0$ mole). After reflux for 20 hour the solvent was removed and the reaction mixture was treated with water, extracted with benzene several times and the collected organic layer was dried on anhydrous $\mathrm{Na}_{2} \mathrm{SO}_{4}$, filtered and evaporated to give liquid ester. ${ }^{1} \mathrm{H} \mathrm{NMR}$ $\left(\mathrm{CDCl}_{3}\right): \delta 1.42\left(\mathrm{t}, 3 \mathrm{H}, \mathrm{CH}_{3}\right), \delta 4.36\left(\mathrm{q}, 2 \mathrm{H}, \mathrm{OCH}_{2}\right), \delta$ 7.42-7.74 (m, 6H, Ar-H). 


\section{2-(Quinolin-8-yloxy) acetohydrazide (2)}

To a RB flask, compound 1 (0.01 mol), hydrazine hydrate $(0.2 \mathrm{~mol})$ and absolute alcohol $(50 \mathrm{~mL})$ were taken. A condenser with calcium guard tube was attached to the flask and mixture was refluxed for 24 hours on water bath. The mixture was concentrated, cooled and poured in crushed ice. It was kept for 3-4 hours at room temperature and solid mass separated out was filtered and dried, recrystallised in methanol. ${ }^{1} \mathrm{HNMR}\left(\mathrm{CDCl}_{3}\right): \delta$ 7.40-7.78 (complex, m, 6H, Ar-H), $\delta$ 7.84-7.98 (m, 3H, $\mathrm{CONHNH}_{2}$ ).

\section{N-(4-Methylphenyl)-2-[(quinolin-8-yloxy) acetyl]hydrazide (3a)}

A mixture of compound 2 (0.001 mole) and 4-methyl phenyl isothiocyanate (0.001 mole) in ethanol $(25.0 \mathrm{~mL})$ was refluxed on a water bath for 2 hour. The solvent was concentrated and the precipitated product was filtered, dried and recrystallised from methanol. 3a IR (KBr): $3387(\mathrm{~N}-\mathrm{H}), 1648(\mathrm{CONH}), 1608(\mathrm{ArH}), 1042(\mathrm{C}=\mathrm{S}) . \quad 3 \mathbf{a}^{1} \mathrm{H}$ NMR $\left(\mathrm{CDCl}_{3}\right): \delta 7.18-7.62(\mathrm{~m}, 6 \mathrm{H}, \mathrm{Ar}-\mathrm{H}), \delta$ 7.70-7.86 (m, 3H, CONHNHCSNH). Other compounds 3b-g were prepared similarly and their characterization data are recorded in Table 1

\section{4-(4-Methylphenyl)-5-[(quinolin-8-yloxy) methyl]-4H-1, 2,4-triazole-3-thiol (4a)}

Compound 3a (0.002 mole) was added to ethanol $(20 \mathrm{~mL})$. To this $\mathrm{NaOH}(4 \mathrm{~N}, 2 \mathrm{~mL})$ was added which resulted in clear solution. It was refluxed for 1 hour and treated with decolorizing charcoal and filtered. The filtrate was cooled and $\mathrm{pH}$ was adjusted to 4-6 with dilute glacial acetic acid. The mixture was kept aside for 1 hour and the crystals produced were filtered, dried and recrystallised from methanol. 4a IR (KBr): $3369(\mathrm{~N}-\mathrm{H}), 1601(\mathrm{C}=\mathrm{N}), 1186(\mathrm{C}=\mathrm{S}) 2922(\mathrm{C}-\mathrm{H}) . \quad 4{ }^{1} \mathrm{H}$ NMR $\left(\mathrm{CDCl}_{3}\right): \delta 3.89(\mathrm{~s}, 2 \mathrm{H}$, $\left.\mathrm{OCH}_{2}\right), \delta$ 7.25-7.88 (complex m, $\left.10 \mathrm{Ar}-\mathrm{H}\right), 10.52(\mathrm{~s}, 1 \mathrm{H}, \mathrm{SH}) . \quad 4 \mathrm{c} \mathrm{IR}(\mathrm{KBr}): 3361(\mathrm{~N}-\mathrm{H})$, $1578(\mathrm{C}=\mathrm{N}), 1208(\mathrm{C}=\mathrm{S}) 2932(\mathrm{C}-\mathrm{H}) .4 \mathrm{c}^{1} \mathrm{H}$ NMR $\left(\mathrm{CDCl}_{3}\right): \delta 3.84\left(\mathrm{~s}, 2 \mathrm{H}, \mathrm{OCH}_{2}\right), \delta$ 7.287.78 (complex m, $10 \mathrm{Ar}-\mathrm{H}), 10.60(\mathrm{~s}, 1 \mathrm{H}, \mathrm{SH})$. Other compounds $3 \mathrm{~b}, 3 \mathrm{c}$ were prepared similarly and their characterization data are recorded in Table 1.

N3-(4-Methoxyphenyl)-5-[(quinolin-8-yloxy)methyl]-4H-1,2,4-triazole-3,4-diamine (5b)

Compound 3b (0.025 mole) and hydrazine hydrate $(0.025$ mole $)$ were refluxed in methanol for 2 hour at a temperature between $50-60^{\circ} \mathrm{C}$, reaction mixture was cooled and poured over crushed ice. Solid was filtered and recrystallised from methanol. 5b IR $(\mathrm{KBr}): 3292(\mathrm{~N}-\mathrm{H}), 1618(\mathrm{C}=\mathrm{N}), 2928(\mathrm{C}-\mathrm{H}) .5 \mathrm{~b}{ }^{1} \mathrm{H} \mathrm{NMR}\left(\mathrm{CDCl}_{3}\right): \delta 2.48\left(\mathrm{~s}, 3 \mathrm{H}, \mathrm{OCH}_{3}\right)$, $\delta 8.26$ (bs, 1H, NH), $\delta$ 7.08-7.96 (complex m, 10 Ar-H). 5a IR (KBr): $3296(\mathrm{~N}-\mathrm{H}), 1623$ $(\mathrm{C}=\mathrm{N}), 2938(\mathrm{C}-\mathrm{H}) . \quad 5 \mathrm{a}{ }^{1} \mathrm{HNMR}\left(\mathrm{CDCl}_{3}\right): \delta 2.28\left(\mathrm{~s}, 3 \mathrm{H}, \mathrm{CH}_{3}\right), 8.24 \quad(\mathrm{bs}, 1 \mathrm{H}, \mathrm{NH}), \delta$ 7.05-7.98 (complex m, $10 \mathrm{Ar}-\mathrm{H}$ ). Other compounds 5a, 5c in the series were prepared similarly and their characterization data are recorded in Table 1

\section{$N$-(4-Methylphenyl)-5-[(quinolin-8-yloxy) methyl]-1,3,4-thiadiazol-2-amine (6a)}

Compound $3 \mathrm{a}\left(0.002\right.$ mole) was added portion wise in $5.0 \mathrm{~mL}$ conc. $\mathrm{H}_{2} \mathrm{SO}_{4}$ and stirred with cooling for $2 \mathrm{~h}$. The mixture was poured over crushed ice and the precipitated solid was filtered, washed with water, dried and recrystallised from methanol. 6a IR (KBr): $3218(\mathrm{~N}-\mathrm{H}), 1626(\mathrm{C}=\mathrm{N}), 3039(\mathrm{C}-\mathrm{H}) .6{ }^{1} \mathrm{H}$ NMR $\left(\mathrm{CDCl}_{3}\right): \delta 5.44\left(\mathrm{~s}, 2 \mathrm{H}, \mathrm{OCH}_{2}\right), \delta 723-$ 7.67 (complex m, $10 \mathrm{Ar}-\mathrm{H}), \delta 7.98(\mathrm{~s}, 1 \mathrm{H}, \mathrm{NH})$. 6f IR $(\mathrm{KBr}): 3412(\mathrm{~N}-\mathrm{H}), 1611(\mathrm{C}=\mathrm{N})$, $2934(\mathrm{C}-\mathrm{H}) . \quad 6 \mathbf{f f}^{1} \mathrm{H} \mathrm{NMR}\left(\mathrm{CDCl}_{3}\right): \delta 5.46\left(\mathrm{~s}, 2 \mathrm{H}, \mathrm{OCH}_{2}\right), \delta$ 7.28-7.74 (complex m, $\left.10 \mathrm{Ar}-\mathrm{H}\right)$, $\delta 7.96(\mathrm{~s}, 1 \mathrm{H}, \mathrm{NH})$. Other compounds $\mathbf{6 b}-\mathrm{g}$ were prepared similarly and their characterization data are recorded in Table 1 


\section{Results and Discussion}

\section{Spectral characterization of the compounds}

The IR spectrum of the compounds (4a-c) showed peaks at $3361-3370 \mathrm{~cm}^{-1}, \mathrm{~N}-\mathrm{H}$ stretching; 2922-2935 $\mathrm{cm}^{-1}$, CH stretching; 1577-1601 $\mathrm{cm}^{-1}, \mathrm{C}=\mathrm{N}$ stretching and 1186$1216 \mathrm{~cm}^{-1}, \mathrm{C}=\mathrm{S}$ stretching. The NMR spectrum of the compound $4 \mathbf{a}$ showed a singlet at $\delta 3.89$ indicating the presence of $\mathrm{OCH}_{2}$ protons. In the aromatic region complex multiplete at $\delta 7.25-7.88$ was observed indicating the presence of ten aromatic protons. A singlet at $\delta 10.52$ was observed for one SH protons. The NMR spectrum of the compound 4c showed a singlet at $\delta 3.84$ indicating the presence of $\mathrm{OCH}_{2}$ protons. In the aromatic region complex multiplete at $\delta$ 7.28-7.78 was observed indicating the presence of ten aromatic protons. Furthermore a singlet at $\delta 10.60$ was observed for one SH protons. The IR spectrum of the compounds (5a-c) showed peaks at 3245-3296 $\mathrm{cm}^{-1}, \mathrm{~N}-\mathrm{H}$ stretching; 2928-2938 $\mathrm{cm}^{-1}, \mathrm{CH}$ stretching; 1618-1624 $\mathrm{cm}^{-1}, \mathrm{C}=\mathrm{N}$ stretching. The NMR spectrum of the compound 5a showed a singlet at $\delta 2.28$ indicating the presence of $\mathrm{CH}_{3}$ protons. In the aromatic region complex multiplete at $\delta$ 7.05-7.98 was observed indicating the presence of ten aromatic protons. A broad singlet at $\delta 8.24$ was observed for one NH protons. The NMR spectrum of the compound $\mathbf{5 b}$ showed a singlet at $\delta 2.48$ indicating the presence of $\mathrm{OCH}_{3}$ protons. In the aromatic region complex multiplete at $\delta$ 7.08-7.96 was observed indicating the presence of ten aromatic protones. A broad singlet at $\delta 8.26$ was observed for one NH protons. The IR spectrum of the compounds (6a-g) showed peaks at 3418-3436 cm $\mathrm{cm}^{-1}, \mathrm{~N}-\mathrm{H}$ stretching; 2928-3039 $\mathrm{cm}^{-1}, \mathrm{CH}$ stretching; 1610-1660 cm $\mathrm{cm}^{-1}, \mathrm{C}=\mathrm{N}$ stretching. The NMR spectrum of the compound $\mathbf{6 a}$ showed a singlet at $\delta 5.44$ indicating the presence of $\mathrm{OCH}_{2}$ protons. In the aromatic region complex multiplete at $\delta$ 7.23-7.67 was observed indicating the presence of ten aromatic protons. A singlet at $\delta 7.98$ was observed for one NH protons. The NMR spectrum of the compound 6 f showed a singlet at $\delta 5.46$ indicating the presence of $\mathrm{OCH}_{2}$ protons. In the aromatic region complex multiplete at $\delta$ 7.28-7.97 was observed indicating the presence of ten aromatic protons. Furthermore a singlet at $\delta 7.96$ was observed for one $\mathrm{NH}$ protons.

\section{Antimicrobial activity}

The synthesized compounds were evaluated for their antimicrobial activity against bacterial strain S. aureus (gram-positive), E. coli (gram-negative) and fungal strain A. niger by cup plate method ${ }^{15}$ at $200,100,50$ and $25 \mu \mathrm{g} / \mathrm{mL}$ concentration. Ofloxacin and Ketoconazole were used as standard drugs for antibacterial and antifungal activity respectively. The minimal inhibitory concentration $\left(\mathrm{MIC}, \mu \mathrm{gmL}^{-1}\right)$ of the tested compounds are recorded in Table 2

The 1,2,4-triazole derivative $4 \mathrm{c}$ having chloro group at para position of phenyl ring exhibited a MIC of $50 \mu \mathrm{g} / \mathrm{mL}$ against, S. aureus, E. coli and A. niger, whereas $4 \mathbf{b}$ exhibited significant antimicrobial activity (MIC $25 \mu \mathrm{g} / \mathrm{mL}$ ) against $S$. aureus and A. niger. The compound $5 \mathbf{a}$ exhibited promising antibacterial activity (MIC $25 \mu \mathrm{g} / \mathrm{mL}$ ) against S. aureus, E. coli and A. niger strains. Compound $\mathbf{5 b}$ exhibited (MIC $25 \mu \mathrm{g} / \mathrm{mL}$ ) against E. coli and A. niger. The 2-(quinolin-8-yloxy) acetohydrazide derivative 6 e having 3-chloro-4-fluorophenyl amino group at $2^{\text {nd }}$ position of thiadiazole ring was found to have MIC $25 \mu \mathrm{g} / \mathrm{mL}$ against S. aureus, E, coli. and A. niger. 1,3,4-thiadiazole derivative 6f also exhibited promising antibacterial activity (MIC $25 \mu \mathrm{g} / \mathrm{mL}$ ) against E. coli. 
Table 2. Antimicrobial activities of the compounds.

\begin{tabular}{cccc}
\hline \multirow{2}{*}{ Compound No. } & \multicolumn{3}{c}{ MIC, $\mu \mathrm{g} / \mathrm{mL}$} \\
\cline { 2 - 4 } & S.aureus & E.coli & Aniger \\
\hline Ofloxacin & 10 & 12.5 & -- \\
Ketoconazole & -- & -- & 12.5 \\
4a & 100 & 100 & 100 \\
4b & 25 & 50 & 25 \\
4c & 50 & 50 & 50 \\
5a & 25 & 25 & 25 \\
5b & 50 & 25 & 25 \\
5c & 50 & 50 & 100 \\
$6 \mathrm{a}$ & 100 & 100 & 100 \\
6b & 100 & 100 & 100 \\
6c & 50 & 100 & 50 \\
6d & 100 & 100 & 100 \\
6e & 25 & 25 & 25 \\
6f & 50 & 25 & 50 \\
6g & 100 & 50 & 50 \\
\hline
\end{tabular}

-- Not tested

\section{Conclusion}

In summary, we have described the genesis and synthesis of antimicrobially active 4-(substituted phenyl)-5-[(quinolin-8-yloxy) methyl]-4H-1,2,4-triazole-3-thiol, $\quad \mathrm{N}^{3}$-(4substituted phenyl)-5-[(quinolin-8-yloxy) methyl]-4H-1,2,4-triazole-3,4-diamine and $\mathrm{N}$-(4substituted phenyl)-5-[(quinolin-8-yloxy) methyl]-1,3,4-thiadiazol-2-amine derivatives. The antimicrobial screening results revealed that some of the compounds are moderately active. However, the activities of the tested compounds are less than those of standard antibacterial and antifungal agents used.

\section{Acknowledgement}

The authors are thankful to the Head, Department of chemistry, for providing laboratory facilities, and to the Head, RSIC-CDRI, Lucknow, for spectral analysis.

\section{References}

1. Boschelli D H, Connor D T, Barnemeier D A, J Med Chem., 1993, 36, 1802-1810.

2. Unangst P C, Shrum G P, Connor D T, Dyer D R, Schrier D J, J Med Chem., 1992, 35, 3691-3698.

3. Amir M, Khan M S Y, Zaman M S, Indian J Chem., 2004, 43B, 2189-2194.

4. Garoufalias S S P, Tani E, Todoulou O, Valiraki A P, Filippatos E, Clercq E D and Kourounakis P N, J Pharm Pharmacol., 1998, 50, 117-124.

5. Hui X P, Zang C H, Wang Q and Zhang Q, Indian J Chem., 2002, 41B, 2176-2179.

6. Tsukuda T, Shiratori Y, Watanade M.H, Ontsuka K, Hattori M, Shirai N and Shimma, Bioorg Med Chem Lett., 1998, 8, 1819-1824.

7. Berk B, Aktay E, Yesilada E and Ertan M, Pharmazie, 2001, 56, 613-616.

8. Holla B S, Poojary K N, Rao B S and Shivananda M K, Eur J Med Chem., 2002, 37, 511-517. 
9. Swamy S N, Basappa, Priya B S, Prabhuswamy B, Doreswamy B H, Prasad J S and Rangappa K S, Eur J Med Chem., 2006, 41, 531-538.

10. Kalgutar A, Marnett A, Crews B, Remmel R and Marnett L, J Med Chem., 2000, 43, 2860-2870.

11. Duflos M, Nourrison M, Brelet J, Courant J, Lebaut G, Grimaud N and Petit J, Eur J Med Chem., 2001, 36, 545-553.

12. Kalgutar A, Crews B, Rowlinson S, Garner C, Siebert K and Marnett L, Science, 1998, 280, 1268-1270.

13. Amir M and Kumar S, Eur J Med Chem., 2004, 39, 535-545.

14. Amir M and Kumar S, Arch Pharm Chem Life Sci., 2005, 338, 24-31.

15. Barry A L, The antimicrobial susceptibility test: principle and practices, Edited by Illuslea and febiger, (Philadelphia, USA) 1976, 180; Biol Abstr, 1977, 64, 25183. 


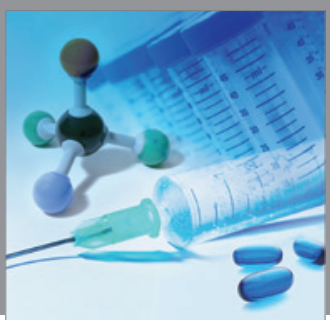

International Journal of

Medicinal Chemistry

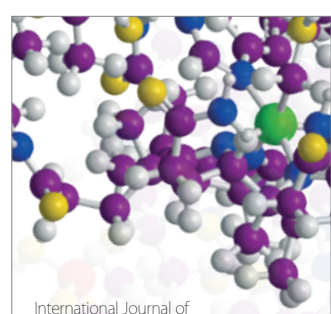

Carbohydrate Chemistry

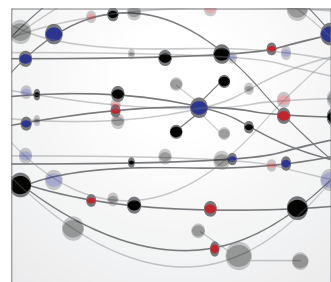

The Scientific World Journal
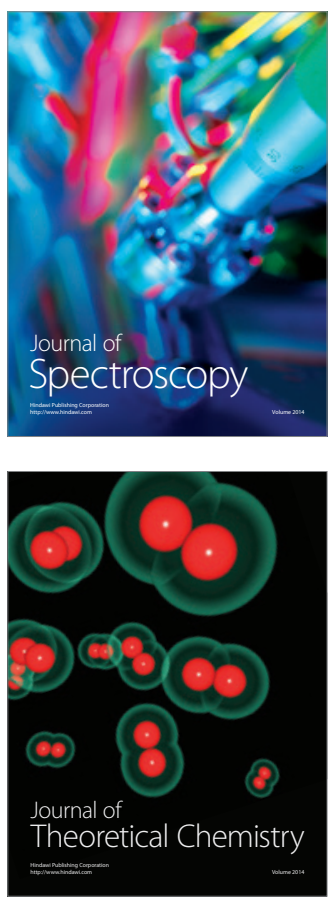
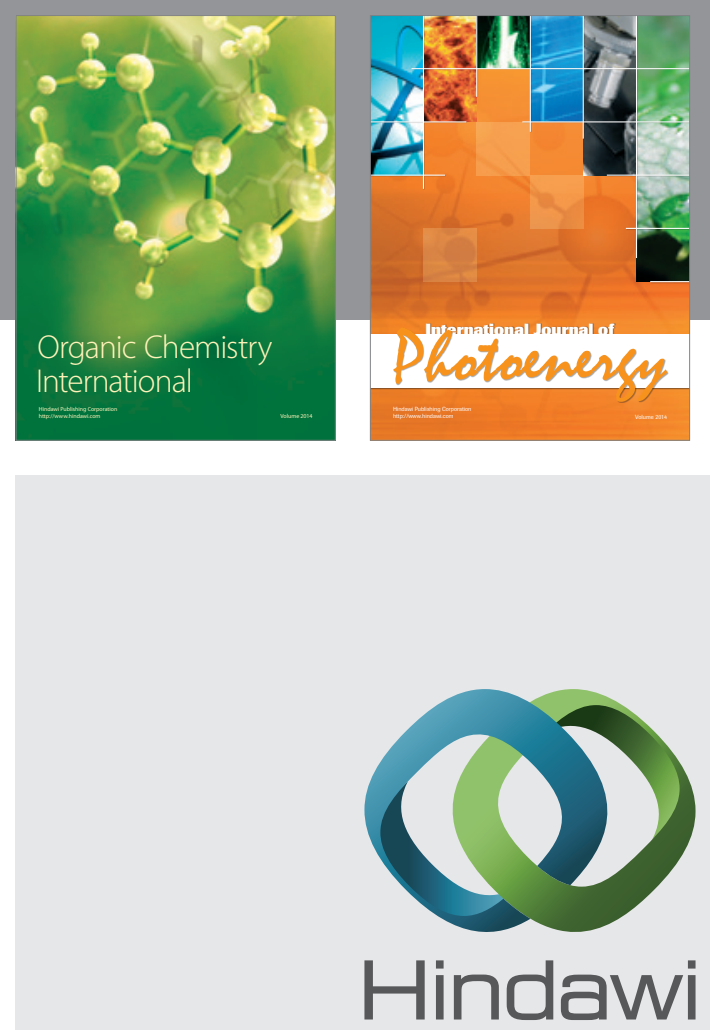

Submit your manuscripts at

http://www.hindawi.com
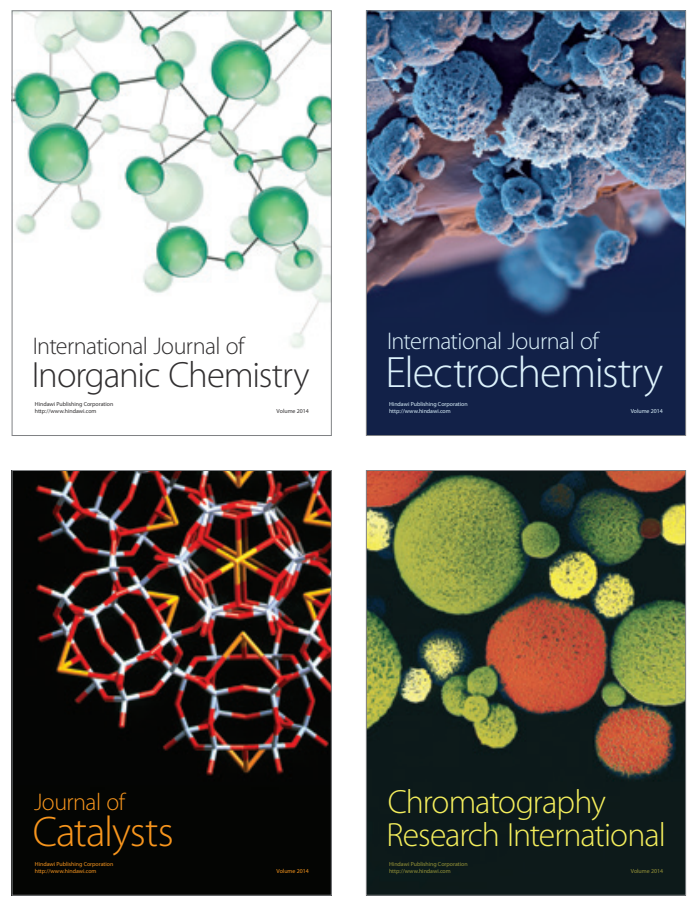
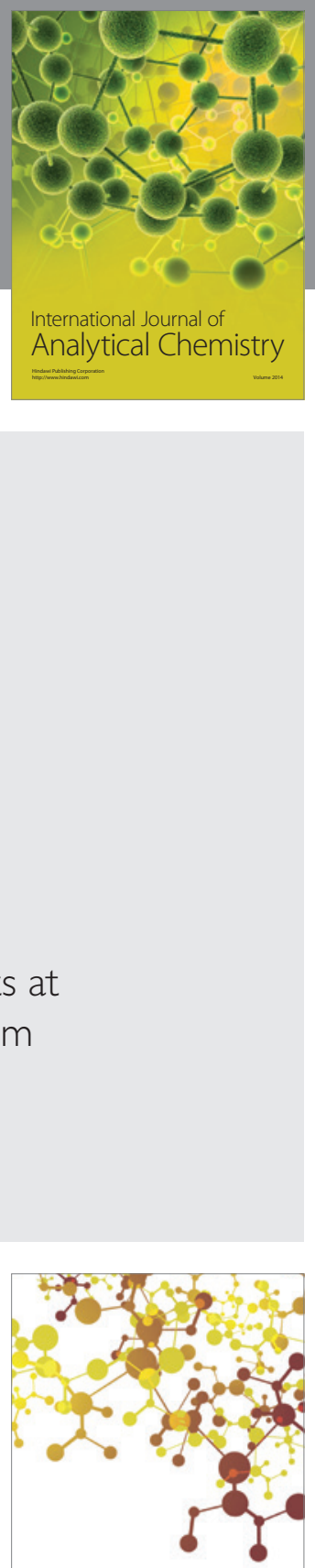

Journal of

Applied Chemistry
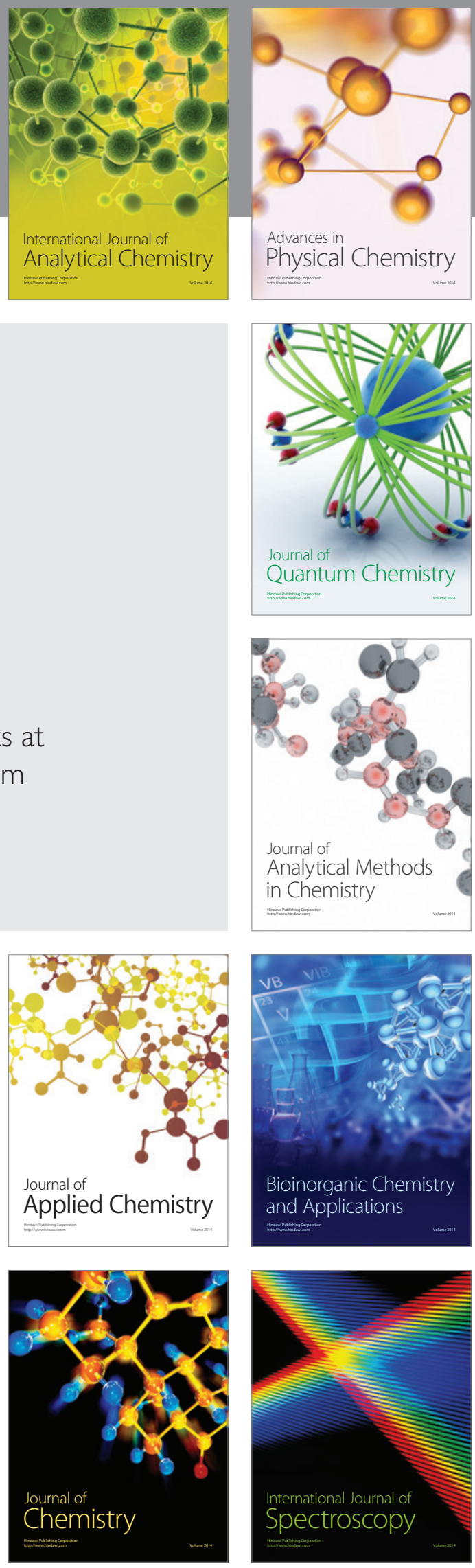